\title{
The Implications of the Chinese "String of Pearls" for the U.S. Return to Asia Policy: the U.S., China, and India in the Indian Ocean
}

\author{
Hankwon Kim
}

Published online: 5 September 2013

(C) CEEUN 2013

\begin{abstract}
This research asks why the United States has kept a skeptical eye on the Chinese "String of Pearls" strategy and enhanced security cooperation with its allies and partners in South and East Asia while continuing to emphasize the necessity for U.S.-PRC economic and strategic cooperation. To answer this question, this article, first, mainly utilizes a realist theoretical approach to determine how the U.S. has evaluated its own comprehensive national power compared to that of China and what the U.S. strategy has been to cope with the increasing naval power of China in the Indian Ocean. This article then attempts to analyze the implications of the Chinese "String of Pearls" for the U.S. rebalancing to Asia. Finally, this article argues that the different values and different interpretations of democracy, human rights, and sovereignty will, for the time being, be the major areas of conflict among the U.S., China, and other neighboring countries rather than direct conflicts in the Indian/West Pacific Oceans.
\end{abstract}

Keywords The U.S $\cdot$ China $\cdot$ India $\cdot$ String of Pearl strategy $\cdot$ South Asia The Indian Ocean

\section{Introduction}

The world has often utilized the term "G2" and asked the U.S. and China (the People's Republic of China, PRC) to solve global problems and to cooperate on furthering the development of international society. While the two have repeatedly emphasized the cooperation between each other, the strategic tension between the U.S. and China has continuously increased in many areas in Asia since the U.S. financial crisis in 2008. The countries neighboring China in Central, Northeast, and

H. $\operatorname{Kim}(\bowtie)$

Center for China Policy, The Asan Institute for Policy Studies, Seoul, Korea

e-mail: hkkim@asaninst.org 
Southeast Asia have shown various strategic behaviors in order to maximize their national interests amidst the competitions and frictions between the U.S. and China. Some countries chose hedging strategies and some have enhanced their alliances or strategic partnerships with one of the two powers.

Unlike these neighboring countries, India has taken an independent position between the U.S. and China. For example, India retains nuclear bombs and has successfully tested its own long-range missile, Agni-V, on April 19, 2012. Besides this, the Indian government accepted the U.S. request to reduce the amount of oil imported from Iran. However, at the same time, an Iranian economic delegation arrived in New Delhi and discussed India-Iran economic cooperation in May, 2012. These two events occurred while the U.S. and China were continuously increasing their naval influence in the Indian Ocean. Indeed, the international structure of South Asia around the Indian Ocean has shown a somewhat different from that of other regions in Asia because of the independent presence of India between the U.S.-PRC power struggles. For that reason, this research focuses on the role of India in the coming competitions between U.S. and Chinese naval power in the Indian Ocean.

This article focuses on the international structure in South Asia and the Indian Ocean from a realist perspective. The movement toward regional integration stemming from economic interdependence and cooperation have grown among the states in Asia, whereas the strategic and military tensions in the region have incrementally emerged after the U.S. financial crisis of 2008, such as (1) the growth of military/security tensions in various parts of East Asia, (2) the continuous security tension between China and India while the economic ties of the two countries have enhanced, (3) the recent trend of confrontation over China-Pakistan versus U.S.-India military cooperation, and (4) the growth of China's naval power in the Indian Ocean and a shifting focus of U.S. naval strategy to the Indian and West Pacific Oceans.

After a brief introduction of the historical background of U.S.-China relations after the Cold War, this article will ask whether the U.S. has really declined since the financial crisis of 2008. To answer this question this article attempts to compare the comprehensive national power of the U.S. and China. Then, its focus will move to South Asia and the Indian Ocean and try to figure out how the U.S., China, and India have recently constitute the regional power structure.

\section{The U.S. Strategy Toward China Since the End of the Cold War Era}

At the end of the Cold War era, the value of China to U.S. strategy rapidly decreased after the collapse of the Soviet Union. Following the Tiananmen Square Incident in June 1989, China was left isolated and suffered from U.S.-led international sanction. At this time, Deng Xiaoping suggested the “taoguangyanghui” (鞱光養晦) strategy and reemphasized the reform and open-up policy through his "Southern Tour" in the early 1992. In the 1990s, Deng's reform policy began significant changes in Chinese society and economy. However, the "rise of China" accompanied "China threat" theories. In the middle of the 1990s, the "China threat" theories pointed to 
China as the fatal threat, or at least the most significant challenge, to U.S. hegemonic power. These theories anticipated an unavoidable collision between the U.S. and China in the near future. In 2003, China began to use the term "peaceful rise” (和平崛起), presented by Zheng Bijian (鄭必堅) in November 2003. In 2004, the Chinese government used the term “peaceful development” (和平发展) instead of the "peaceful rise." The term "harmonious world" has been utilized since 2005. Therefore, during that time, the major debate regarding the U.S.-PRC relationship mainly stemmed from the two countries' different perspectives on the emerging Chinese influence, which was based on the rapid economic development and its influence in the world society.

After the U.S. financial crisis at the end of 2008, many people expected that U.S. leadership and hegemonic power would be in decline and, at the same time, that China's reemergence would be just a matter of time. China showed rigid and assertive stances on various issues between 2009 and 2010: An unarmed U.S. Navy ship, Impeccable, was harassed by Chinese ships in March 2009 in blue water off the coast of China (China announced it happened in the Chinese EEZ.); Chinese Foreign Minister Yang Jiechi (杨洁簏) warned Southeast Asian countries not to coordinate with outside powers in dealing with territorial disputes with China at the ASEAN Regional Forum in July 2010; China demanded Japan give apology and compensation for detaining a Chinese fishing boat captain in the same year; and the Chinese government twice warned the U.S.-ROK joint military drills after North Korean military provocations, including the sinking of the South Korean warship Cheonan and the shelling of Yeonpyong island, which happened on March 26 and November 23, 2010 respectively. In 2010, China's relationship with the U.S. further deteriorated, particularly over the issue of China hacking important U.S. governmental institutions, the meeting between President Obama and the Dalai Lama, U.S. export of arms to Taiwan, and the U.S. support for Southeast Asian countries vis-avis China in territorial disputes.

\section{Has the U.S. Really Declined Since 2008?}

It is true that the U.S. has harmed its global leadership after the financial crisis, and China's cooperation is needed more than ever to solve various global problems, such as those of Syrian issues, Iran and North Korea's nuclear problems, and the recovery of the world economy. However, at the moment, it looks a little early to accept the assumptions that the U.S. is in decline or that there will be a reemergence of China based only on the earlier examples. China has achieved rapid growth, it deserves to take pride in its economic development, it has taken a higher position in international society, and China has expanded its military capacity, especially with regard to its Navy power.

Yet, compared to current U.S. economic power, military influence, and international leadership, China still has far to go. Based on GDP figures, China surpassed Japan in 2012 and became the world's second largest economic power. In 2011, the U.S. GDP was recorded to be over US\$ 15 trillion, while the GDP of China was approximately US\$ 7 trillion. The trend in past decades may indicate that 
Table 1 The GDP and GDP per capita of the U.S. and PRC

\begin{tabular}{|c|c|c|c|c|c|c|c|c|}
\hline & 2010 & 2011 & 2012 & 2013 & 2014 & 2015 & 2016 & 2017 \\
\hline \multicolumn{9}{|l|}{ The U.S. } \\
\hline GDP & $14,526.55$ & $15,094.03$ & $15,609.70$ & $16,221.38$ & $16,940.57$ & $17,783.57$ & $18,705.03$ & $19,704.59$ \\
\hline $\begin{array}{l}\text { GDP per } \\
\text { capita }\end{array}$ & $46,900.39$ & $48,386.69$ & $49,601.41$ & $51,057.58$ & $52,816.95$ & $54,920.84$ & $57,220.23$ & $59,707.87$ \\
\hline \multicolumn{9}{|l|}{ PRC } \\
\hline GDP & $5,930.39$ & $7,298.15$ & $7,991.74$ & $8,777.20$ & $9,641.85$ & $10,581.05$ & $11,598.97$ & $12,713.86$ \\
\hline $\begin{array}{l}\text { GDP per } \\
\text { capita }\end{array}$ & $4,421.00$ & $5,413.57$ & $5,898.57$ & $6,446.07$ & $7,045.85$ & $7,693.71$ & $8,391.90$ & $9,152.77$ \\
\hline
\end{tabular}

GDP (Billion U.S. \$)/GDP per capita (U.S. \$)

* Estimates start after year 2011

** Data from IMF

the GDP gap between the U.S. and China will surely decrease in the near future (see Table 1).

However, we should not depend too much on GDP figures to evaluate the two states' economic power. At the moment, the GDP of the U.S. is still more than twice that of China. Moreover, the GDP per capita of China in 2011 was approximately a ninth of the GDP per capita of the United States. Asides from the figures, the U.S. was ranked the fourth in global economic competitiveness while China was named 27th, according to the data from World Economic Forum (WEF). In fact, the U.S. was far ahead of China in terms of the amount of R\&D investment, opportunity for entrepreneurship, the cooperation between industry and schools, and the level of education of its labor force, etc. ${ }^{1}$

Secondly, in terms of military power and security leadership, the U.S. is significantly ahead of China in various categories. First of all, the defense budget of the U.S. was about US\$ 739 billion in 2011, while China was US\$ 89.8 billion. In 2011 , the U.S. annual defense budget was 8 times more than that of China. The Chinese government notably announced on March 4, 2012 that its annual defense budget is about US\$ 106 billion, which is an $11.2 \%$ increased from the previous year. ${ }^{2}$ In fact, Chinese annual budget figures form the last 10 years have shown an annual increase of between 10 and 15 percent. ${ }^{3}$ Many scholars and experts on Chinese security policy have regarded Chinese annual defense budget figures reported by the Chinese government as reduced and unauthentic because of its using a different calculation method from the U.S. and other Western powers. Furthermore, in March 2012, Washington announced that it would curtail its defense budget by about US\$ 259 billion over the next 5 years. Therefore, the budget gap between the U.S. and China would be significantly reduced in the near future. At the same time, China has acquired its first aircraft carrier, Varyag, then later renamed it as Liaoning, and established the A2/AD strategy to cope with the

\footnotetext{
1 Nye (2010), pp. 6-7.

2 Department of Defense (2012).

3 International Institute For Strategic Studies (2012), p. 215.
} 


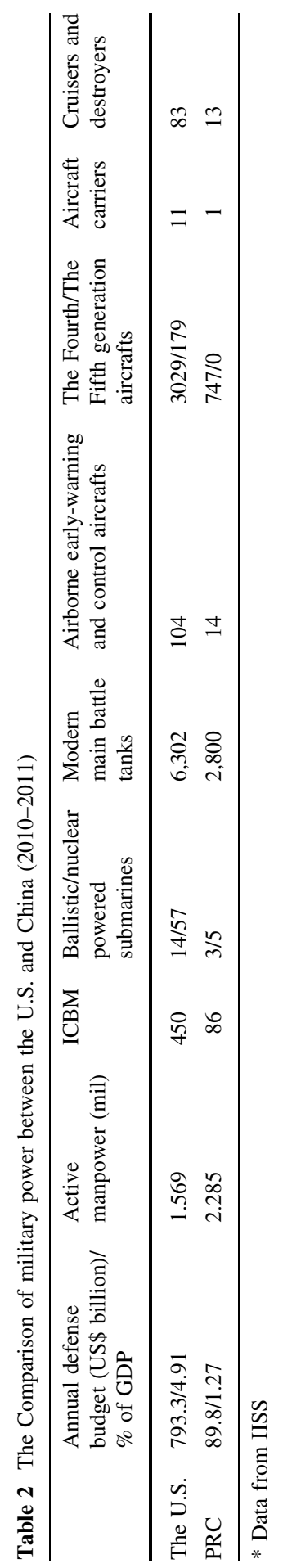


asymmetrical military capacities of the United States. However, if we compare current military capacities between the two countries in detail, the U.S. is far ahead of China at this time (see Table 2). Furthermore, U.S. security leadership and influence in various regions in Asia have been promoted through the enhancement of security cooperation with its allies and partners, while China has increased security tensions with its neighboring countries in Asia over territorial disputes as well as aggressive policies and behavior since the Lehman Shock of 2008.

Thirdly, the U.S. retains universal values and norms, such as democracy, human rights, and free-market capitalism, which are important points when comparing comprehensive national power between the U.S. and China. China has tried to establish China's own values and norms based on Confucianism and zhonghua (中华) ideology. Also the tianxia (all-under-heaven, 天下) ideology advocated by Zhao Tingyang has recently dispersed over Chinese society and has offered theoretical support for 'Socialism with Chinese characteristics' as well as for the rejection of ideas of Western democracy and human rights norms. ${ }^{4}$

However, they are not yet considered universal ideas. Also, Chinese arguments that the state should give more weight to sovereignty rather than human rights and that every state's sovereignty cannot be harmed by interruption from other states for any reasons have not yet gained full support from most member states of international society. Furthermore, many Chinese experts in the International Relations field argue that the U.S. has not declined as much as some Chinese people assert. Wang Jisi argues that Chinese grand strategy was not shifted after the U.S. financial crisis of 2008 and many hard-liners and nationalists in China should not hold onto their radical claims of the need for a readjustment of the U.S.-China relationship or the enlarged role of China in the international society. ${ }^{5}$ Wang and Kenneth Lieberthal both emphasize cooperation, based on building "strategic trust," between the U.S. and China for solving frictions between the two countries as well as global problems. ${ }^{6}$ Chu Shulong and Chen Songchuan also argue that it is true that the U.S. global influence and national comprehensive power have decreased in the last few years. However, in the long run, there have not been fundamental changes in U.S. economic, technological, or military; international influence; or cultural strength since the financial crisis. ${ }^{7}$

\section{The Naval Confrontation in South Asia and the Indian Ocean}

According to the written history of the two countries, their relationship started with commercial trade in the second century B.C. Buddhism was first introduced into China from India in the first century. With the introduction of Buddhism and Indian traditional cultural development, China could not easily maintain a feeling of cultural superiority vis-à-vis India. Their relationship declined on account of

\footnotetext{
4 Zhao (2005).

5 Wang (2011).

${ }^{6}$ Lieberthal and Wang (2012).

7 Chu and Chen (2011)
} 
Western imperial colonialism. After India's independence from Great Britain and the establishment of the People's Republic of China, the two countries resumed their diplomatic relations. On April 1, 1950, the two countries normalized their diplomatic relationship, and Chinese Premier Zhou Enlai and Indian Prime Minister Jawaharlal Nehru signed "the five principles of peaceful coexistence" in June 1954.

However, their peaceful relationship was broken by the escape of the Dalai Lama and other Tibetan religious and political leaders to India in 1959 and the border conflicts in 1962. Afterwards, China was successful in its nuclear test in October 1964 and in December of the same year. The Indian government officially announced its own nuclear development plan and finally materialized it in 1974. In the 1960s and 1970s, India led the non-alignment movement and acted as a leader among the third world countries. On the other hand, the Indian government also maintained an amicable relationship with the Soviet Union based on the IndiaSoviet Treaty of Friendship and Cooperation of 1971. To cope with the India-Soviet relationship, China readjusted its relationship with the U.S. in the early 1970s and enhanced its security cooperation with Pakistan. China's technological and military support for Pakistan brought about a deeper Indian distrust of China. Although China and India restored their diplomatic relationship in August 1976 and resumed official bilateral trade in 1978, the distrust between the two countries has remained.

In the post-Cold War era, the demise of the Soviet Union meant to India in many respects, a loss of a diplomatic partner that supported India's claims in the border conflicts around Kashmir, its security partner who balanced against Sino-Pakistan military cooperation, and its advanced weaponry supplier. The Indian government finally conducted the second nuclear tests on May 11 and 13, 1998. Besides the Soviet factor, India faced internal and external difficulties. Internally, the Hindunationalist Bharatiay Janta Party grasped domestic political power. Externally, the U.S. and other nuclear powers passed the Comprehensive Test Ban Treaty (CTBT) in 1996, and Pakistan conducted an intermediate-range missile test in March 1998, named Ghauri, that could target 26 major cities in India.

On the other hand, China and India attempted to solve border frictions through diplomatic measures. Beginning with Indian Prime Minister Rajiv Gandhi's visitation to Beijing in 1988, the two governments maintained regular high-level meetings in the 1990s. In fact, China made huge efforts to solve the border problems with its neighboring countries from the mid-1990s and solved, or partially solved, the problems with Kyrgyzstan (1996), Kazakhstan (1998), Russia (2008), Vietnam (2008), and Tajikistan (2011). In terms of China and India border conflicts, the Indian government acknowledged Chinese sovereignty over the Tibet area in 2003, and the Chinese government, in return, recognized Indian sovereignty over the Sikkim area at the end of 2005.

However, bilateral border frictions resumed when China claimed that a southern part of the McMahon Line was China's territory in 2006. At the same time, the number of lootings by Chinese troops around the border has significantly increased (140 times in 2006 to 270 times in 2008). The Chinese government also constructed 5 air bases in the Tibetan area. To cope with China's behaviors, the Indian government reinforced its troops on the border and launched a military modernization program, spending US\$ 100 billion for 10 years. At last, India shifted its 
security grand strategy form the "Cold Start" toward Pakistan to the "Two-Front War" doctrine vis-a-vis both Pakistan and China in December 2009.

Recently, the U.S. and neighboring countries of China in South and East Asia have carefully watched the growth of China's naval capabilities. Indeed, the expansion of China's naval operation coverage to the Indian Ocean through dispatches of naval warships to Somalia in 2008 and the development of naval-base ports and naval-base-use-related ports in Gwadar (Pakistan), Chittagong (Bangladesh), Kyaukphyu (Myanmar), along with the "String of Pearls," have made the U.S. and China's neighboring countries concerned about the naval expansion of China more than ever. Therefore, China's "String of Pearls" strategy has been highlighted as a central security issue in South Asia, especially after the U.S. pivot policy toward Asia. China has explained the "String of Pearls" is intended to secure its energy-supply route from the Indian Ocean via the Malacca Strait to the Southern China for China's stable economic development. On the contrary, the U.S. and India have regarded it as Chinese military expansionism to the oceans and as a coming threat from the sea against their own interests. For that reason, the U.S. and India have recently enhanced their security cooperation.

Aside from security tensions between China and India, the bilateral relationship in other dimensions has gone well in the last decade. In particular, their bilateral economic relationship has shown notable development. The Sino-India trade volume, which was US\$2.92 billion in 2000, increased to US\$ 73.9 billion in 2011. After the financial crisis of 2008, the trade volume declined by around 16 percent, but it immediately recovered in the following year see Table 3). Based on the China-India Joint Economic Group on Economic Relations and Trade, Science and Technology (JEG) which was established when former Indian Prime Minister Rajiv Gandhi visited Beijing in 1988, the two governments agreed to sign up to the China-India Strategic and Economic Dialogue (SED) in December 2010. The first meeting of the SED was held in Beijing on September 26, 2012. The two countries are also sharing the goal of expanding their bilateral trade volume to US $\$ 100$ billion in 2015. However, the trade deficit of India has emerged as an important problem in the bilateral economic relationship and to further cooperation. The deficit has increased from US\$15.87 billion in 2009 to US\$27.08 billion in 2011 .

Table 3 Sino-India International trade 2009-2011 (US\$ billions)

\begin{tabular}{lccc}
\hline & 2009 & 2010 & 2011 \\
\hline China exports to India & 29.57 & 40.88 & 50.49 \\
Growth (\%) & -6.17 & 38.25 & 23.5 \\
India exports to China & 13.7 & 20.86 & 23.41 \\
Growth (\%) & -32.63 & 52.19 & 12.26 \\
Total China-India trade & 43.28 & 61.74 & 73.9 \\
Growth (\%) & -16.55 & 42.66 & 19.71 \\
\hline
\end{tabular}

* Data from the General Administration of Customs of the People's Republic of China 


\section{U.S.-China-India Trilateral Structure in South Asia and the Indian Ocean}

China's reinforcement of its naval power in the Indian Ocean as well as the U.S. rebalance to Asia policy have remarkably impacted the regional security tensions among the U.S., China and other South Asian countries. Some experts expect U.S.Australia-India cooperation in the Indian Ocean to cope with China's naval expansion. ${ }^{8}$ However, India's reactions to China and the U.S. approaches to the region have shown that India accepts cooperation to a certain degree with the U.S. but keeps its independent posture in the regional international power structure. To explain the independent India's reactions, I will introduce two recent cases.

Case 1: The U.S. Sanctioning of Iran and India's Reaction

To curb Iran's nuclear ambitions, the U.S. government requested major Iranian-oil importing countries to stop their oil trade with Iran. The U.S. government wanted to diminish the inflow of oil money to Iran, which could be easily utilized to develop Iran's nuclear program. India and China immediately objected to the U.S. request because it could harm the national interests of India and China. Although the Indian government tried to show a clear stance against U.S. pressure, the Indian government conducted an internal review to reduce the amount of imported oil from Iran. As a result, India's decision on this issue is a very interesting one. While the Indian government emphasized strategic cooperation with the U.S. during Secretary of State Hillary Rodham Clinton's visit to New Delhi in May 2012, the Indian government also met an economic delegation from Iran and reached an agreement that India would pay Iran for a part of its oil with Indian rupees, and Iran would purchase necessary goods from Indian markets with the rupee. The U.S. government tacitly tolerated this agreement because India's choice, at least, could deter the U.S. dollar flowing into Iran as payment for Iranian oil. As a result, the U.S. and India found equilibrium between the two countries chasing their own national interests and strategic goals.

\section{Case 2: India's Long-range Missile Test}

On April 19, 2012, India was successful in testing a long-range missile, Agni V. Many experts believe the Agni V has 3100-mile strike distance, which means Indian could target China's major cities. The Chinese government recognized the success of India's missile test and emphasized the mutual friendship between the two countries. Unlike the case of the North Korean "satellite" test in April 13, 2012, the U.S. government did not denounce the Indian missile test, but rather seemed to enjoy the strategic calculation of India's missile capability being able to reach China. It is also notable that India's missile test heightened regional security tensions. Pakistan, the traditional opponent of India, also announced that it had launched a successful intermediate-range missile test, Haft-VII, on April 25, 2012, only 6 days after the Indian test.

\footnotetext{
${ }^{8}$ Cutis et al. (2011).
} 
With India's missile test, India clearly demonstrated two important points. First, India wants to enhance security cooperation with the U.S. to cope, to some extent, with China's naval power in the Indian Ocean, but, at the same time, it is clear that the Indian government does not promote cooperation with the U.S. to establish an alliance relationship. Second, as was the case with two earlier Indian nuclear tests in 1974 and 1998, India has shown its self-reliance and independent stance toward an ever-changing regional power structure and national security concerns in the regional environment. It could be interpreted that India has historical experience and memories of Western colonialism and military conflicts with China on the one hand and that India has maintained an image as a leading country of the non-aligned movement on the other.

\section{Conclusion}

As many experts have observed, issues in the Sino-India relationship has transformed from bilateral to multilateral concerns. ${ }^{9}$ Through multilateral approaches, there are various scenarios to expect in the future regional power structure in South Asia and the Indian Ocean. For example, some scholars and experts argue that the U.S.-Australia-India bloc will eventually confront the ChinaPakistan-Russia bloc. However, this article argues that, rather than being a matter of competition between two opposing blocs, there is, in fact, a trilateral overlapping balance of shared and diverging interests among the U.S., China, and India. This is because India has shown an independent and self-reliant stance between the U.S. and China through its reaction to U.S. sanctions on Iran and India's long-range missile test in 2012. It is definitely true that India needs to cooperate with the U.S. to cope with the increasing naval capability of China in the Indian Ocean and the unsolved border dispute. U.S. and Indian security cooperation will be only enhanced up to a finite degree because India has chosen "balance of threat" for its own national security strategy rather than "balance of power." Although India has already realized the asymmetric comprehensive national power between China and the U.S., India has perceived China as a "revisionist state" and a threat. In other words, the Indian government has chosen to cooperate with the U.S. to protect itself from the neighboring threat of Sino-Pakistan military cooperation, rather than making efforts to balance within the regional power structure (i.e. cooperation with China to balance against the U.S.). In other words, India interpreted China's naval assertiveness to secure its energy-transport route in the Indian Ocean as an "expansion" of a rising China that can directly harm India's national interests. At this point, the U.S. and China share the perception of Chinese expansionism, and this shared perception facilitates their cooperation to cope with China in South Asia and the Indian Ocean.

However, as the country that retains nuclear bombs and long-range missiles, that maintains an image of being the leader of the non-alignment movement, and that has memories of Western colonialism and border conflicts with China, U.S.-India

\footnotetext{
${ }^{9}$ See Singh (2011).
} 
cooperation will be operated within limits. Moreover, the recent significant decline of India's economic condition could urge the Indian government to actively enhance economic ties with China. Indeed, the Indian economy has declined since the financial crisis in 2008. In particular, the Indian rupee has already devalued by about $13 \%$ since February 2012, and the inflation, decreasing investment from foreign countries, and increasing trade deficit have emerged as the major obstacles to recovering the Indian economy.

In spite of the limits to the U.S.-India cooperation, there is a high possibility of the emergence of a classical problem in international relations, namely the "security dilemma," in South Asia and the Indian Ocean. As we can see, China increased its naval power to secure its energy transport route from the Indian Ocean via the Malacca Strait to Southern China, but India accepted this as China's expansion to South Asia and the Indian Ocean, and then decided to enhance its missile capacity with its recent long-range missile test. India's reaction brought about a serious security concern for Pakistan, the traditional rival state of India, and it reactively led to Pakistan's own missile test, as well as cementing Pakistan's military cooperation with China. India then needs, to some extent, security cooperation with the U.S. At the same time, the U.S. has actively engaged in Asian affairs. The presence of the U.S. in South Asia and the Indian Ocean, along with the partnership with India, may cause Chinese concern about the security of its energy route, which may lead China to further reinforce its naval power in the region in the future.

Finally, the border conflict between China and India has been the central factor in the mutual distrust between the two countries. Furthermore, the escape of the Dalai Lama with Tibetan leadership to India in 1959 and the military cooperation between China and Pakistan have been the major causes of the deterioration in the bilateral relationship. However, this article views, that in the near future, different values and norms in terms of democracy, human rights, and the state sovereignty will be the major area of conflict among the U.S., China, and other neighboring countries for the time being, rather than direct conflicts in the Indian/West Pacific Oceans. China and India do not want any military conflicts in South Asia and the Indian Ocean because it is very obvious that such conflict would directly harm their national interests. Also, the U.S. strategic goal in the region is not victory over China but containing Chinese expansion through enhanced cooperation with neighboring countries. However, in order to increase their soft power as well as their justification of their cooperation, the U.S. and India may continuously raise questions on the issues of China's characteristic socialist democracy and minority issues especially in the Tibet and Xinjiang areas.

\section{References}

Chu S, Chen S (2011) Meiguozai zouxiang shuaituima? (Is the U.S. moving to declination?). Xiandaiguojiguanxi (the Contemporary International Relations). No. 4

Cutis L et al (2011) Shared goals, converging interests: a plan for U.S.-Australia-India cooperation in the Indo-Pacific. Online available http://www.lowyinstitute.org/files/pubfiles/Shared_goals\%2C_ converging_interests.pdf 
Department of Defense (2012) Annual Report to Congress: Military and Security Developments involving the People's Republic of China

International Institute For Strategic Studies (2012) The military balance

Lieberthal K, Wang J (2012) Addressing U.S.-China Strategic Distrust. The John L. Thornton China Center at Brookings Monograph Series. No. 4

Nye JS Jr (2010) The future of American power: dominance and decline in perspective. Foreign Affairs $89: 6$

Singh S (2011) Paradigm shift in India-China relations: from bilateralism to multilateralism. J Int Affairs $64: 2$ (spring/summer)

Wang J (2011) China's search for a grand strategy: a rising great power finds its way. Foreign Affairs 90:2

Zhao T (2005) Tianxia Tixi: Shijie zhidu zhexue daolun (The Tianxia system: a philosophy for the world Institution). Jiangsu Jiaoyu Chubanshe, Nanjing 